\title{
Phytoremedial potential of maize (Zea mays L.) hybrids against cadmium (Cd) and lead $(\mathrm{Pb})$ toxicity
}

Misbah Rasool ${ }^{1}$, Muhammad Anwar-ul-Haq ${ }^{1}$, Muhammad Jan², Javaid Akhtar $^{1}$, Muhammad Ibrahim ${ }^{3}$ and Javed Iqbal ${ }^{4}$

1. Institute of Soil and Environmental Science, University of Agriculture, Faisalabad-Pakistan

2. Department of Soil and Environmental Science, Ghazi University, Dera Ghazi Khan-Pakistan

3. Department of Agronomy, Ghazi University, Dera Ghazi Khan, 32200-Pakistan

4. Soil and Water Testing Laboratory for Research, Dera Ghazi Khan-Pakistan

*Corresponding author's email: mjanleghari@gmail.com, mjan@gudgk.edu.pk

Citation

Misbah Rasool, Muhammad Anwar-ul-Haq, Muhammad Jan, Javaid Akhtar, Muhammad Ibrahim and Javed Iqbal. Phytoremedial potential of maize (Zea mays L.) hybrids against cadmium $(\mathrm{Cd})$ and lead $(\mathrm{Pb})$ toxicity. Pure and Applied Biology. Vol. 9, Issue 3, pp1932-1945. http://dx.doi.org/10.19045/bspab.2020.90206

\begin{tabular}{|c|c|}
\hline Received: $05 / 02 / 2020$ & "Revised: 25/04/2020 \\
\hline
\end{tabular}

\section{Abstract}

Heavy metals are contaminants of much environmental apprehension, as they are hazardous to human being and other biota. The chelates react with the heavy metals and free that metal from the cation exchange sites and resulting the metal chelated species and move readily into the soil. For this purpose, a hydroponic stud was conducted in wire house of Saline Agricultural Research Center to monitor the potential of Maize (Zea mays L.) cultivars against cadmium (Cd) and lead $(\mathrm{Pb})$ toxicity. A chelated source Ethylene Diamine Tetra Acetic acid (EDTA) was used to evaluate the uptake of $\mathrm{Cd}$ and $\mathrm{Pb}$. The experiment was comprised of nine treatments. As $\mathrm{T}_{1}=\mathrm{Control}, \mathrm{T}_{2}=$ Cd 25 ppm, $\mathrm{T}_{3}=\mathrm{Pb} 50$ ppm, $\mathrm{T}_{4}=\mathrm{Cd} 50$ ppm, $\mathrm{T}_{5}=\mathrm{Pb} 100$ ppm, $\mathrm{T}_{6}=\mathrm{Cd} 25$ ppm+EDTA, $\mathrm{T}_{7=} \mathrm{Cd} 50$ ppm+EDTA, $\mathrm{T}_{8}=\mathrm{Pb} 50$ ppm+EDTA and $\mathrm{T}_{9}=\mathrm{Pb} 100$ ppm+EDTA. Two maize cultivars Syngenta8711 and 33H-25 were used. It was concluded that the parameters like shoot fresh and dry weight, chlorophyll content (SPAD value) and relative water content decreased under toxic level of Cadmium $(\mathrm{Cd})$ and Lead $(\mathrm{Pb})$. The addition of EDTA increased the uptake of $\mathrm{Cd}$ and $\mathrm{Pb}$ which ultimately reduced the overall the plant growth. Among the maize hybrids, maximum $\mathrm{Cd}$ concentration was observed in Syngenta-33-H-25 while minimum in Syngenta-8711 at all cadmium stress levels. At all the lead stress levels the maximum $\mathrm{Pb}$ concentration was observed in Syngenta-33-H-25. The minimum Pb concentration was recorded in Syngenta-8711 at all lead stress levels.

Keywords: Cadmium; Chelated; Chlorophyll content; Lead; Maize

\section{Introduction}

Maize is one of the most important food crop in the world and together with rice and wheat provides at least $30 \%$ of the food calories to more than 4.5 billion people in 94 developing countries and worldwide its production was
1,123.65 million tons [1]. Pakistan produces an annual 3.1 million tons of maize covering an area of 1.04 million hectares giving 2,984 $\mathrm{kg} / \mathrm{ha}$ grain yield on average, making it the third most valuable cereal of the country and the production has increased from 0.38 to 
3.037 million tons during the last 6 decades [2].

The substantial metal incorporates naturally essential, for example, cobalt (Co), copper $(\mathrm{Cu})$, chromium $(\mathrm{Cr})$, manganese $(\mathrm{Mn})$ and zinc $(\mathrm{Zn})$ and non-essential. For example the components of mercury $(\mathrm{Hg})$, lead $(\mathrm{Pb})$ and cadmium $(\mathrm{Cd})$. The non-essential metals are generally known as poisonous components for plants, human and creatures. Both the groups are dangerous to plants, creatures and people at higher concentration [3]. Heavy metals are actually present in soils in low focus yet there is consistent flood through atmospheric deposition, utilization of metal tainted sewage slime, fertilizers [4] and effulent irrigation water [5]. Many experts in the world have turned out to be cognizant about the immediate or backhanded impact of heavy metals on human health, spread of irresistible diseases brought on by fungi, bacteria and other worm infections [6-7].

Out of 6634 registered industries, 1228 are considered highly polluting in Pakistan [8]. Furthermore, $90 \%$ cities lack the facility of effluent treatment. Untreated city effluent is generally used for irrigating vegetables, wheat, rice, fodder and legumes. There is no comprehensive figure about the extent of wastewater used for irrigation. However, available total estimate of effluent irrigated area is 20 mha in the world. In Pakistan, effluent irrigated area is about 32,500 ha [9] Peri-urban areas in big cities like Lahore, Faisalabad, Gujranwala, Multan, Rawalpindi, Peshawar and Hyderabad are receiving raw sewage for irrigation. Easy access, ensured supply, and nutrient value of raw effluents attract its use; despite having higher levels of heavy metals, soluble salts, pathogens. Although the concentration of heavy metals in sewage effluents is low, long-term use for irrigation often results in buildup of metals in soils which is ultimately taken up by plants and enters into food chain [10].
Accessibility of metals to plants is an intricate capacity of many elements including inception of metals, aggregate fixation, metal speciation, temperature, physical and additionally concoction properties of soils and plant genetic makeup [11]. Also, metal conduct and bioavailability is alert in the earth and is impacted by soil properties, for example, $\mathrm{pH}$, natural matter, soil arrangement ionic quality, $\mathrm{Mn}$ and Fe oxides, redox potential and nature of sorbing surfaces [12-13]. Metals have diverse affinities for various ligand particles in this way impacting particle combine and complex particle development which influence their mobility and solubility [14]. Chelation means "to grab" or "to bind." When EDTA is injected into the veins, it "grabs" heavy metals and minerals such as lead, mercury, copper, iron, arsenic, aluminum, and calcium and removes them from the body. Except as a treatment for lead poisoning, chelation therapy is controversial and unproved [15]. Our present understanding is that effluent is a huge source of irrigation water with some to considerable plant nutrition. If not properly used, it is of environmental concern. Heavy metal buildup in soils is another serious issue and needs action of industries owners, policy makers and farmers to reduce the risk of contamination. More site specific research is needed to overcome future crises of water shortage along with its monitoring and safe use. The scientists should go to the technology package investigation for reducing the metal contamination in food chain. Soil is an ultimate sink for contaminants so the social attitude should be positive for effluent farming. Phosphorus fertilizers are another source of heavy metals such as $\mathrm{Cd}$, so its long term use needs the understanding in addition to its effect on uptake of other metals [16-17].

The contamination with heavy metals has become a serious threat to the environment and food security because of rapid 
development in agriculture and industry, as well as disturbance of the natural ecosystem due to the enormous growth in world population [18]. Soil heavy metal pollution has become a worldwide environmental issue that has attracted considerable public attention largely from the increasing concern for the security of agricultural products [19]. Globally, there are 5 million sites of soil pollution covering 500 million ha of land, in which the soils are contaminated by different heavy metals or metalloids, with the present soil concentrations higher than the geobaseline or regulatory levels [20]. Heavy metal pollution in soil has a combined worldwide economic impact estimated to be in excess of US\$10 billion per year [21].

Cadmium is highly mobile in soil and its concentration regarding uncontaminated soils usually varies from 0.5 to $3.0 \mathrm{mg} \mathrm{kg}$-1 [22]. However, $\mathrm{Pb}$ concentration in the Earth's anterior is generally $<50 \mathrm{mg} \mathrm{kg}^{-1}$. $\mathrm{Pb}$ has strong affinity with organic and/or colloidal materials in the soil and is generally available in low concentration for plant uptake. Literature shows that metal-organic matter complexes in soil solution are involved in significant environmental and ecological processes such as availability, solubilization, and transport of metals [23].

Thus the objectives of the study were to the effect of moderate and higher doses of $\mathrm{Cd}$ and $\mathrm{Pb}$ on maize cultivars and to study the effect of synthetic chelator (EDTA) in the translocation and uptake of $\mathrm{Cd}$ and $\mathrm{Pb}$.

\section{Materials and methods}

\section{Experimental conditions and plant material}

To assess the capability of Maize (Zea mays L.) cultivars against cadmium $(\mathrm{Cd})$ and lead $(\mathrm{Pb})$ harmfulness a hydroponic study was conducted. At first maize seeds grown in plate (sand culture) in a green house. For water system refined water utilized amid development of maize seedlings. Following ten days old Maize seedlings of comparable size was transplanted into plastic tubs (containing arrangement culture). The $1 / 2$ quality Hoagland's solution [24] was connected to satisfy supplements request of the plant. The $\mathrm{pH}$ of the solution was checked and kept up in the range of 6.0 to 6.5 by utilizing $0.1 \mathrm{~N} \mathrm{HCl}$ and $0.1 \mathrm{~N} \mathrm{NaOH}$. In the hydroponic framework, maize plants was evaluated at 0,25 and $50 \mathrm{mg} \mathrm{L}^{-1}$ of $\mathrm{Cd}$ and 0 , 50 and $100 \mathrm{mg} \mathrm{L}^{-1}$ of $\mathrm{Pb}$ in the nonappearance and nearness of EDTA @ $0.25 \mathrm{~g} \mathrm{~L}^{-1}$. All the plastic tubs were circulated air through tenderly with an air compressor for $24 \mathrm{~h}$. The treatment of $\mathrm{Pb}$ were made by using lead nitrate salt $\left(\mathrm{Pb}\left(\mathrm{NO}_{3}\right)_{2}\right.$ having $98 \%$ purity while $\mathrm{Cd}$ treatments were formulated by using Cadmium Chloride salt $\mathrm{CdCl}_{2}$ having $99.90 \%$ purity. One and half months old maize seedlings were subjected to diagnostic and development parameters as per standard methods as given below.

\section{Plant parameters}

After the duration of 45 days, plants were harvested, and left for sun drying. Samples were oven dried to constant weight and weighed with a spring balance and yield per plant was recorded. After oven drying, samples were grinded and one gram sample was digested with a mixture of digested in a di-acid $\left(\mathrm{HNO}_{3}: \mathrm{HClO}_{4}\right)$ mixture [25]. Potassium and sodium in the digested material were determined with a flame photometer (Jenway, PFP-7). The $\mathrm{Cd}$ and $\mathrm{Pb}$ concentration in the digest was estimated by atomic absorption spectrophotometer (AAS).

\section{Statistical analysis}

All values reported in this study are means for three replicates. A two-way analysis of variance (ANOVA) was performed utilizing a measurable bundle, SPSS form 16.0 (SPSS, Chicago, IL). LSD test was done to compare the contrast between the treatments [26].

\section{Results and discussion}

Shoot fresh weight (g plant ${ }^{-1}$ )

Plant biomass was severely affected due to toxic effect of heavy metals level 
consequently; shoot fresh weight was reduced. The data regarding the means of shoot fresh weight of maize genotypes under control and different levels of $\mathrm{Cd}$ and $\mathrm{Pb}$ are presented in (Fig. 1). Four weeks of heavy metals stress strongly reduced shoot fresh weight. The impact of heavy metals toxicity, however, differed substantially between maize cultivars. Based on this data, it was observed that maize cultivar Syngenta-8711 showed less reduction (on an average, $72 \%$ and $79 \%$ of control shoot fresh weight at toxic levels of $\mathrm{Cd}$ and $\mathrm{Pb}$ respectively). Maize cultivar Syngenta-33H-25, on the contrary, showed much greater sensitivity to $\mathrm{Cd}$ and $\mathrm{Pb}$ (on an average $90 \%$ and $92 \%$ of control shoot fresh weight at toxic level of $\mathrm{Cd}$ and $\mathrm{Pb}$ respectively). In general, shoot fresh and dry weight of Syngenta-8711 was less affected as compared to Syngenta-33H-25.

The addition of EDTA significantly decreased the plant biomass due to more uptake of $\mathrm{Cd}$ and $\mathrm{Pb}$. Syngenta-8711 (on an average, $69 \%$ and $72 \%$ of control shoot fresh weight at toxic levels of $\mathrm{Cd}$ and $\mathrm{Pb}$ respectively) while Syngenta-33H-25, on the contrary, showed much greater sensitivity to $\mathrm{Cd}$ and $\mathrm{Pb}$ on an average $87 \%$ and $92 \%$ of control shoot fresh weight at toxic levels of $\mathrm{Cd}$ and $\mathrm{Pb}$ respectively).

Shoot dry weight (g plant ${ }^{-1}$ )

Four weeks of heavy metals stress strongly reduced both shoot dry weight (Fig. 2). Plant biomass was severely affected due to toxic effect of heavy metals level which ultimately reduced the shoot dry weight. A significant difference was observed among the maize hybrids. It was observed that the maize cultivar Syngenta-8711 showed less reduction (on an average, $97 \%$ and $89 \%$ of control shoot dry weight at toxic levels of $\mathrm{Cd}$ and $\mathrm{Pb}$ respectively). Maize cultivar Syngenta-33H-25, on the contrary, showed much greater sensitivity to $\mathrm{Cd}$ and $\mathrm{Pb}$ (on an average $92 \%$ and $93 \%$ of control shoot dry weight at toxic level of $\mathrm{Cd}$ and $\mathrm{Pb}$ respectively). In general, shoot fresh and dry weight of Syngenta-8711 was less affected as compared to Syngenta-33H-25.

The addition of EDTA significantly decreased the plant biomass due to more uptake of $\mathrm{Cd}$ and $\mathrm{Pb}$. Syngenta-8711 (on an average, $86 \%$ and $93 \%$ of control shoot dry weight at toxic levels of $\mathrm{Cd}$ and $\mathrm{Pb}$ respectively) while Syngenta-33H-25, on the contrary, showed much greater sensitivity to $\mathrm{Cd}$ and $\mathrm{Pb}$ on an average $84 \%$ and $88 \%$ of control shoot dry weight at toxic levels of $\mathrm{Cd}$ and $\mathrm{Pb}$ respectively).

These results are also in agreement with the findings of some other researches. They observed that maize biomass production adversely reduced due to the toxicity of $\mathrm{Cd}$ and $\mathrm{Pb}$ which results actually due to the inhibiting effect of $\mathrm{Cd}$ and $\mathrm{Pb}$ on plant metabolic and photosynthetic process which considered as most important process of plant growth. Similarly findings was also reported by [27-28] in case of maize crop. EDTA addition to the treatment systems increased the uptake of heavy metals by plants and decreased the shoot fresh weight which was also supported by the findings of [29], EDTA much pronounced with $\mathrm{Cd}$ and $\mathrm{Pb}$. However, the pattern of uptake by plants was similar as that of heavy metals without EDTA amendments [30].

These results are also in agreement with the findings of some other researches [31-32]. They observed that maize biomass production adversely reduced due to the toxicity of $\mathrm{Cd}$ and $\mathrm{Pb}$ which results actually due to the inhibiting effect of $\mathrm{Cd}$ and $\mathrm{Pb}$ on plant metabolic and photosynthetic process which considered as most important process of plant growth. EDTA addition to the treatment systems increased the uptake of heavy metals by plants and decreased the shoot fresh weight. EDTA much pronounced with $\mathrm{Cd}$ and $\mathrm{Pb}$. However, the pattern of uptake by plants was similar as that of heavy metals without EDTA amendments [33]. 


\section{Chlorophyll content (SPAD)}

Means of chlorophyll content of maize genotypes under control and different levels of $\mathrm{Cd}$ and $\mathrm{Pb}$ are presented in (Fig. 3). Plants chlorophyll content was severely affected due to toxic effect of heavy metals level consequently; shoot and root fresh weight was reduced. Four weeks of heavy metals stress strongly reduced chlorophyll content. The impact of heavy metals toxicity, however, differed substantially between maize cultivars. Based on this data, we identified the maize cultivar Syngenta-8711 showed less reduction (on an average, $86 \%$ and $82 \%$ of control chlorophyll content at toxic levels of $\mathrm{Cd}$ and $\mathrm{Pb}$ respectively). Maize cultivar Syngenta-33H-25, on the contrary, showed much greater sensitivity to $\mathrm{Cd}$ and $\mathrm{Pb}$ (on an average $83 \%$ and $85 \%$ of control chlorophyll content at toxic level of $\mathrm{Cd}$ and $\mathrm{Pb}$ respectively). In general, chlorophyll content of Syngenta-8711 was less affected as compared to Syngenta-33H25.

The addition of EDTA significantly decreased the chlorophyll content due to more uptake of $\mathrm{Cd}$ and $\mathrm{Pb}$. Syngenta-8711 (on an average, $79 \%$ and $73 \%$ of control chlorophyll content at toxic levels of $\mathrm{Cd}$ and $\mathrm{Pb}$ respectively) while Syngenta-33H-25, on the contrary, showed much greater sensitivity to $\mathrm{Cd}$ and $\mathrm{Pb}$ on an average $73 \%$ and $78 \%$ of control chlorophyll content at toxic levels of $\mathrm{Cd}$ and $\mathrm{Pb}$ respectively).

\section{Relative water content (RWC)}

Means of relative water content of maize genotypes under control and different levels of $\mathrm{Cd}$ and $\mathrm{Pb}$ are presented in (Fig. 4). Plant biomass was severely affected due to toxic effect of heavy metals level consequently; relative water content was reduced. Four weeks of heavy metals stress strongly reduced both shoot and root fresh weight. The impact of heavy metals toxicity, however, differed substantially between maize cultivars. Based on this data, we identified the maize cultivar Syngenta-8711 showed less reduction (on an average, $82 \%$ and $83 \%$ of control relative water content at toxic levels of $\mathrm{Cd}$ and $\mathrm{Pb}$ respectively). Maize cultivar Syngenta-33H-25, on the contrary, showed much greater sensitivity to $\mathrm{Cd}$ and $\mathrm{Pb}$ (on an average $91 \%$ and $90 \%$ of control relative water content at toxic level of $\mathrm{Cd}$ and $\mathrm{Pb}$ respectively). In general, relative water content of Syngenta-8711 was less affected as compared to Syngenta-33H-25.

The addition of EDTA significantly decreased the relative water content due to more uptake of $\mathrm{Cd}$ and $\mathrm{Pb}$. Syngenta-8711 (on an average, $72 \%$ and $75 \%$ of control relative water content at toxic levels of $\mathrm{Cd}$ and $\mathrm{Pb}$ respectively) while Syngenta-33H-25, on the contrary, showed much greater sensitivity to $\mathrm{Cd}$ and $\mathrm{Pb}$ on an average $70 \%$ and $66 \%$ of control relative water content at toxic levels of $\mathrm{Cd}$ and $\mathrm{Pb}$ respectively).

The different results for chlorophyll content were presented by [34] who investigated the effect of $\mathrm{Cd}^{+2}$ in different concentrations for content of maize chlorophyll content. The reduction in chlorophyll content was as reported by some other researches [35] observed that $\mathrm{Cd}$ is more toxic to reduce the chlorophyll content compared to $\mathrm{Pb}$. The addition of EDTA also caused a significant reduction due to more uptake of $\mathrm{Cd}$ and $\mathrm{Pb}$ which ultimately reduce the chlorophyll content which is as in the agreement with the findings of [36].

A decrease of water content in plants under the influence of HM was observed by many researchers [37]. The effect of HM on water exchange was evidenced by the reduction of leaf size and stomata [38], and by a decrease of turgor which resulted in a reduction of the water potential and probably was the reason for growth inhibition [39].

Cadmium concentration ( $\mathrm{mg} \mathrm{kg}^{-1}$ ) in shoot Maximum concentration of $\mathrm{Cd}$ was observed in the treatment where $\mathrm{Cd}$ was applied at higher concentration compared to the control 
treatment. The concentration of $\mathrm{Cd}$ are presented in (Fig. 5). Maximum concentration of $\mathrm{Cd}$ in shoot were recorded up to $8.86 \mathrm{mg} \mathrm{kg}^{-1}(168 \%)$ in response to 50 ppm Cd + EDTA While, minimum $\mathrm{Cd}$ concentration was observed in $25 \mathrm{ppm} \mathrm{Cd}$ treatment. By increasing the concentration of $\mathrm{Cd}$ level, concentration also increased. Maximum concentration in shoot was observed by the combination of higher dose of Cd and EDTA.

An increase in $\mathrm{Cd}$ concentration was observed by increasing the level of $\mathrm{Cd}$ however the addition of EDTA increased the $\mathrm{Cd}$ concentration as compared to no EDTA. The chelators increased the uptake of heavy metals and the use of chelators mobilizes the metals to the root zone [40]. Some other researchers [41-42] also reported that the addition of EDTA increased the metal uptake in maize crop by making a complex with metal [43] also reported that the addition of EDTA increased the $\mathrm{Cd}$ concentration in broad bean.

\section{Lead concentration $\left(\mathrm{mg} \mathrm{kg}^{-1}\right)$ in shoot}

The concentration of $\mathrm{Pb}$ in shoot were recorded up to $75.00 \mathrm{mg} \mathrm{kg}^{-1}$ (145\%) in response to $100 \mathrm{ppm} \mathrm{Pb}+$ EDTA While, minimum $\mathrm{Pb}$ concentration was observed in $50 \mathrm{ppm} \mathrm{Pb}$ treatment. Results about $\mathrm{Pb}$ concentration in shoot are presented in (Fig. 6). By increasing the concentration of $\mathrm{Pb}$ level, concentration also increased. Maximum concentration in shoot was observed by the combination of higher dose of $\mathrm{Pb}$ and EDTA.

Once the metal has been expelled from the cation exchange sites, it can be taken up by plant roots. A standout amongst the most capable and regularly utilized chelating operators is ethylene diamine tetra acidic corrosive (EDTA), which shapes edifices with a considerable lot of the metal contaminants inside the natural environment. The most ordinarily utilized and compelling chelator is EDTA [44]. Although powerful at preparing metals, and increased the $\mathrm{Pb}$ concentration and uptake indifferent pant parts. Same findings were also reported by [45] in rice crop they observed that the addition of EDTA increased the $\mathrm{Pb}$ uptake and ultimately reduced the whole plant growth.

Cadmium uptake (mg Plant $\left.{ }^{-1}\right)$ and in shoot Maximum uptake of $\mathrm{Cd}$ in shoot was recorded up to $0.93 \mathrm{mg}$ plant $^{-1}(163 \%)$ in response to $50 \mathrm{ppm} \mathrm{Cd}+$ EDTA while minimum Cd uptake was observed in $25 \mathrm{ppm}$ $\mathrm{Cd}$ treatment. By increasing the concentration of $\mathrm{Cd}$ level, uptake also increased. Maximum uptake in shoot was observed by the combination of higher dose of Cd and EDTA (Fig. 7).

Cadmium uptake increased by increasing the level of $\mathrm{Cd}$ and the addition of EDTA increased the uptake as compared to EDTA. [46] also observed that the application of EDTA was ineffective uptake of $\mathrm{Cd}$, with the addition of EDTA Cd uptake was higher in the stems and lower in the roots.

\section{Lead uptake (mg Plant ${ }^{-1}$ ) and in shoot}

Maximum uptake of $\mathrm{Pb}$ in shoot were recorded up to $7.60 \mathrm{mg}^{-1 a n t^{-1}}(124 \%)$ in response to $100 \mathrm{ppm} \mathrm{Pb}+$ EDTA While, minimum $\mathrm{Pb}$ concentration was observed in $50 \mathrm{ppm} \mathrm{Pb}$ treatment. By increasing the concentration of $\mathrm{Pb}$ level, uptake also increased. Maximum uptake in shoot was observed by the combination of higher dose of $\mathrm{Pb}$ and EDTA (Fig. 8).

The chelating agents enhanced the transport of $\mathrm{Pb}$ from roots to shoots, such as H-EDTA and EDTA, while the concentration of $\mathrm{Pb}$ in the roots decreased sharply. So $\mathrm{Pb}$ can be easily transported in plants in the forms of $\mathrm{Pb}$ chelators complexes $[47,48]$ identified that $\mathrm{Pb}$-EDTA complex was transported through plant and accumulated in the leaves. In rice, it was also reported that the root structure was damaged by excessive $\mathrm{Na}$, resulting in 
Pure Appl. Biol., 9(3): 1932-1945, September, 2020

http://dx.doi.org/10.19045/bspab.2020.90206

enhanced flow of $\mathrm{Na}$ into the xylem vessels and increased accumulation of $\mathrm{Na}$ in the shoot [49].

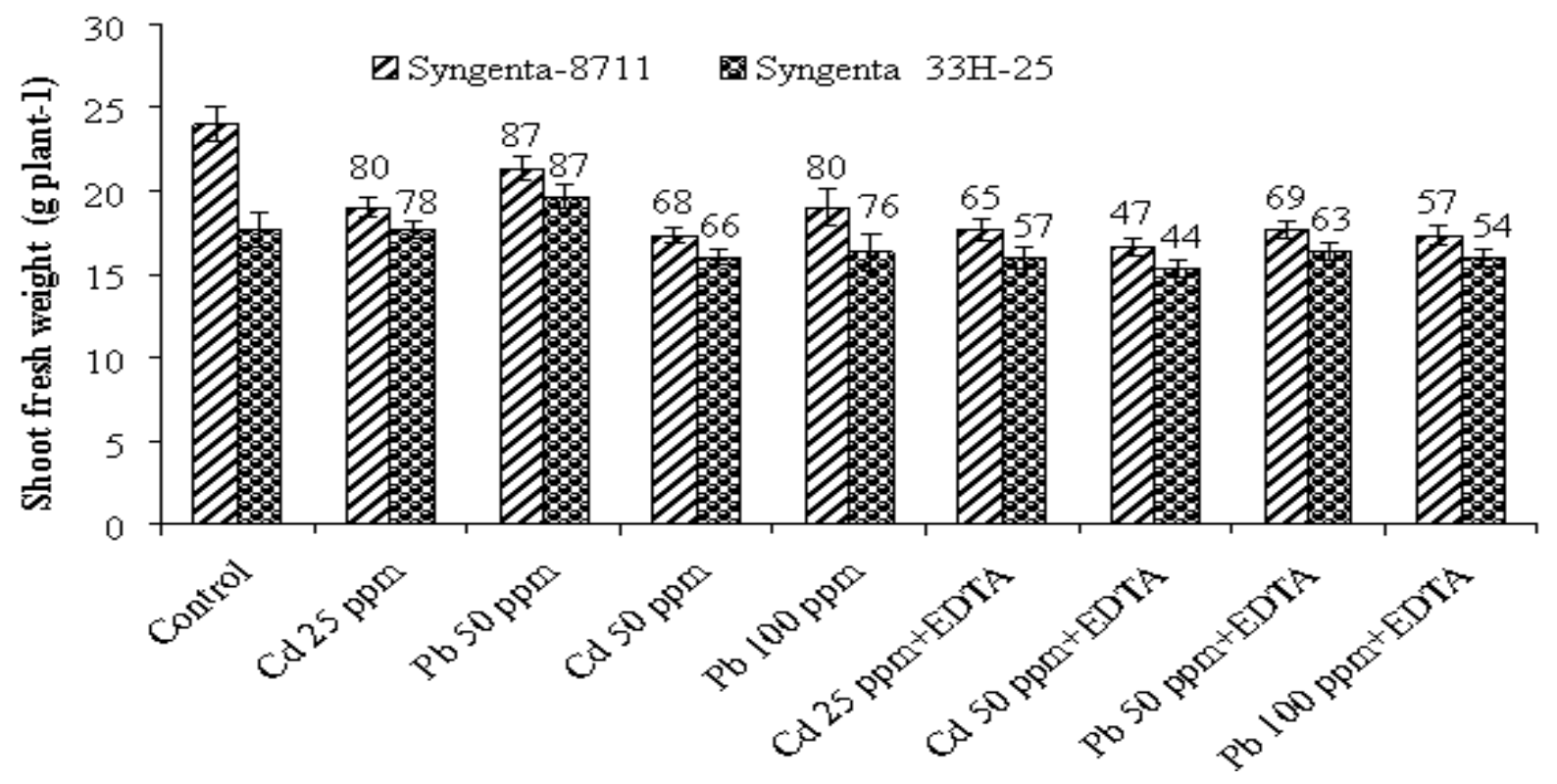

Figure 1. Effect of different concentrations of cadmium $(\mathrm{Cd})$ and lead $(\mathrm{Pb})$ on shoot fresh weight of Maize cultivars

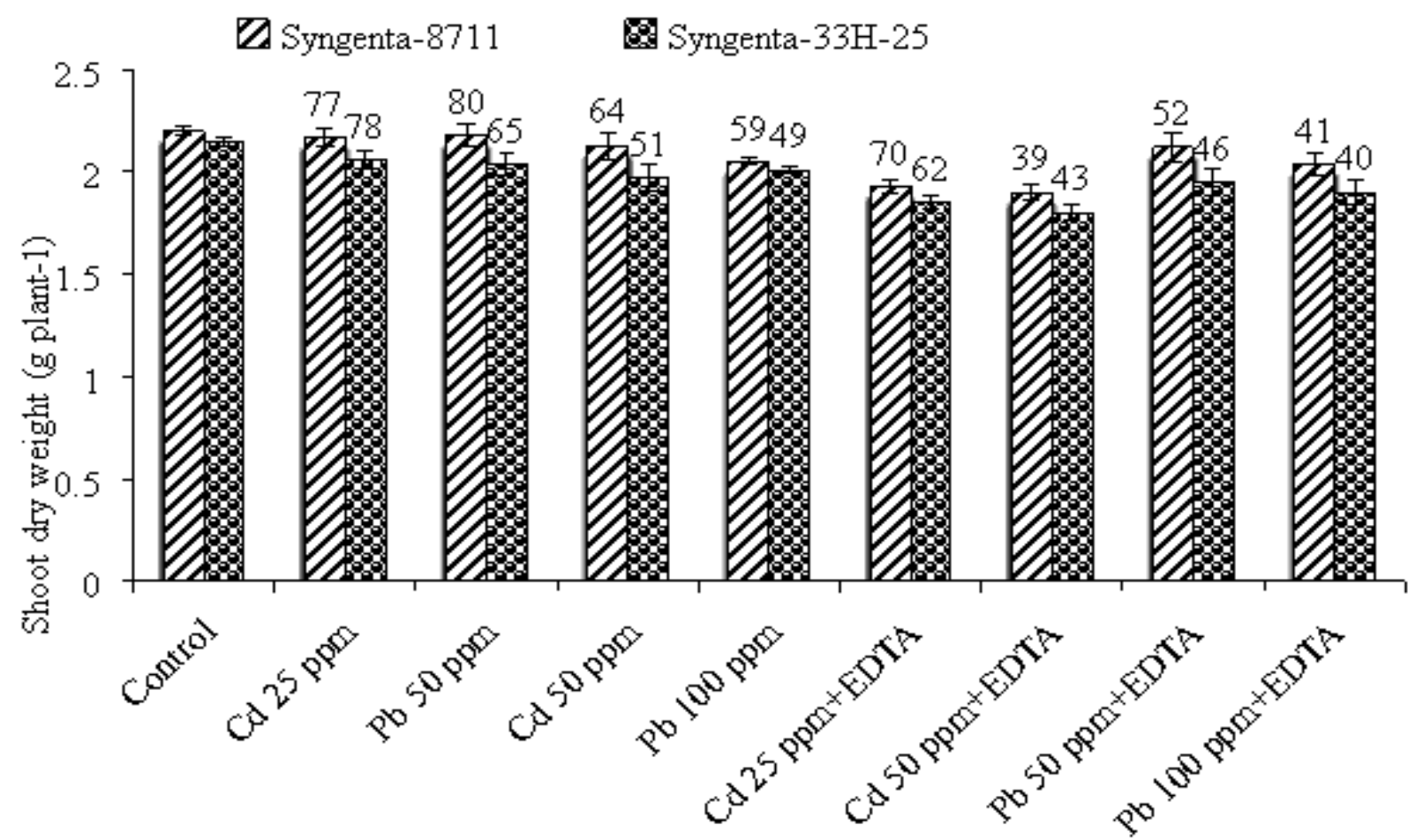

Figure 2. Effect of different concentrations of cadmium (Cd) and lead (Pb) on shoot dry weight of Maize cultivars 


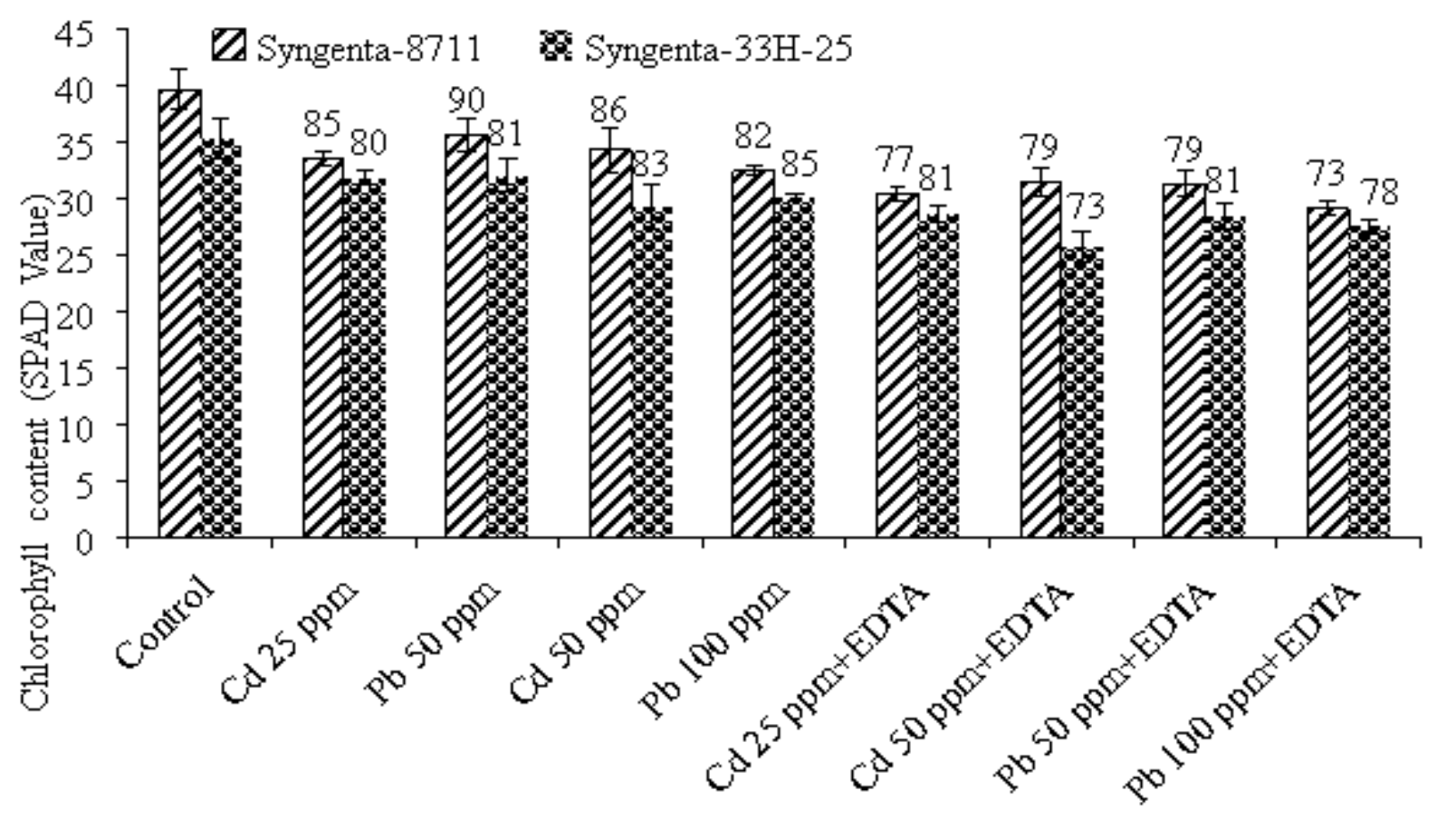

Figure 3. Effect of different concentrations of cadmium $(\mathrm{Cd})$ and lead $(\mathrm{Pb})$ on chloropyll content of Maize cultivars

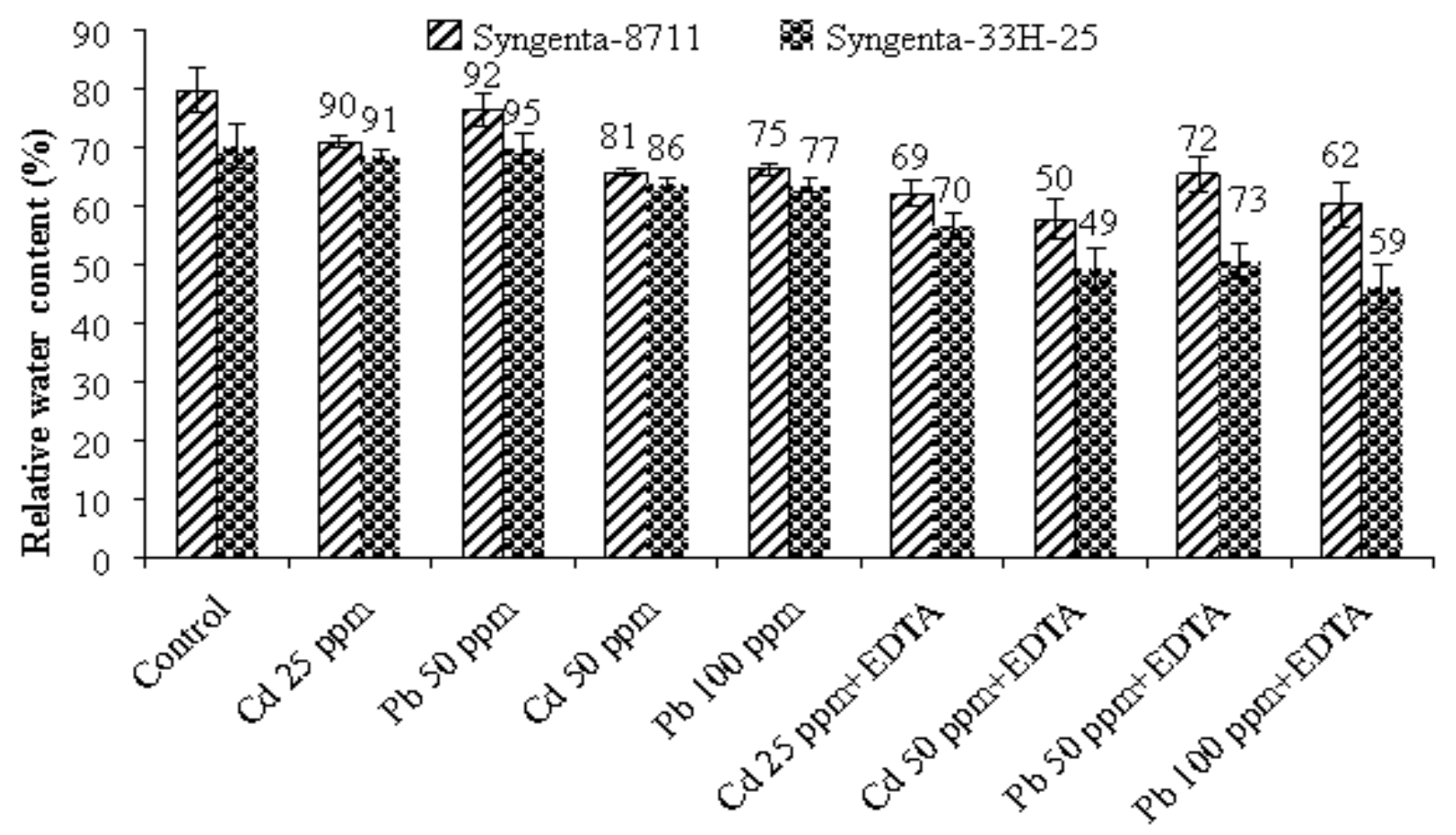

Figure 4. Effect of different concentrations of cadmium $(\mathrm{Cd})$ and lead $(\mathrm{Pb})$ on relative water content of Maize cultivars 
Pure Appl. Biol., 9(3): 1932-1945, September, 2020

http://dx.doi.org/10.19045/bspab.2020.90206

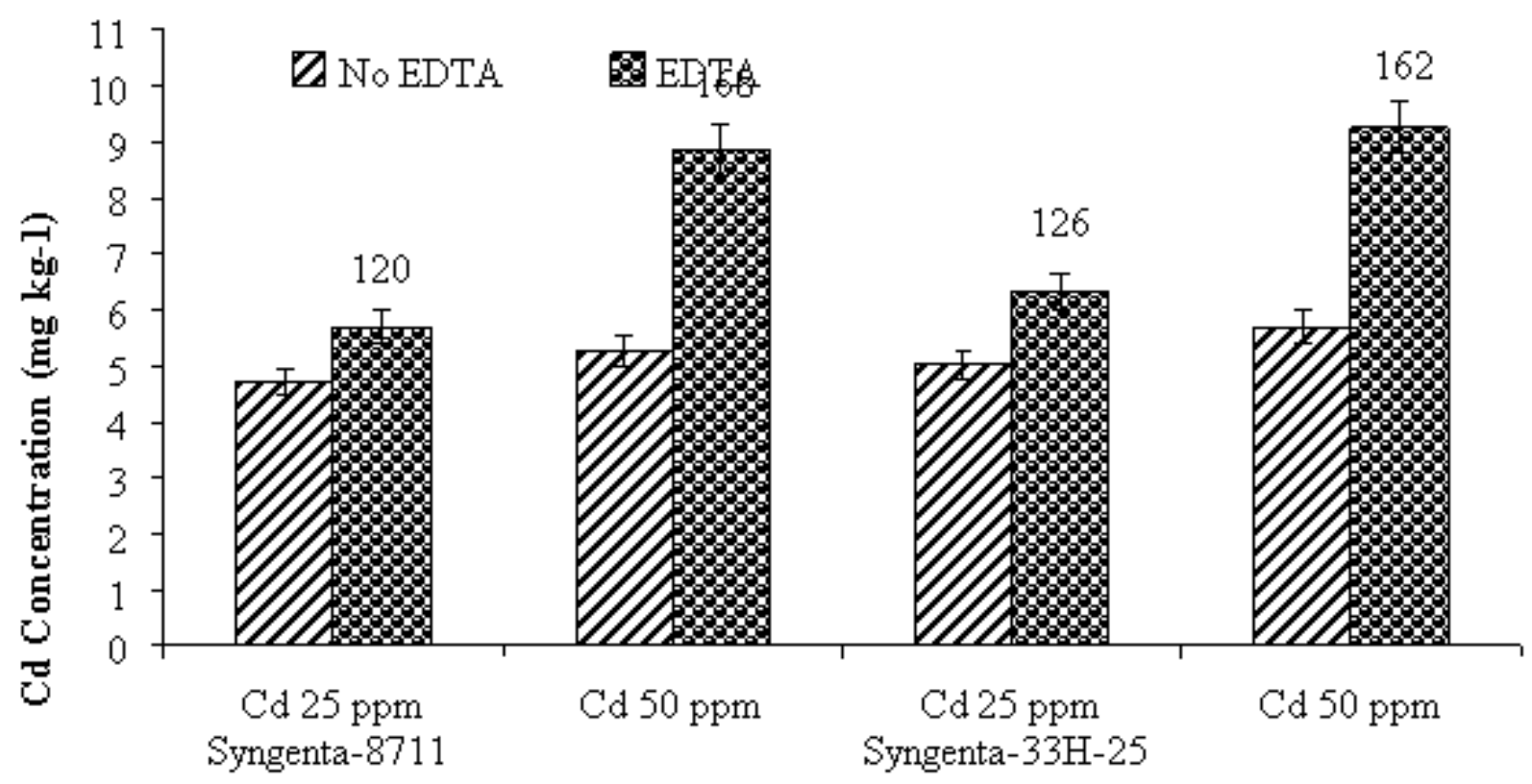

Figure 5. Effect of different concentrations of cadmium (Cd) on Maize cultivars

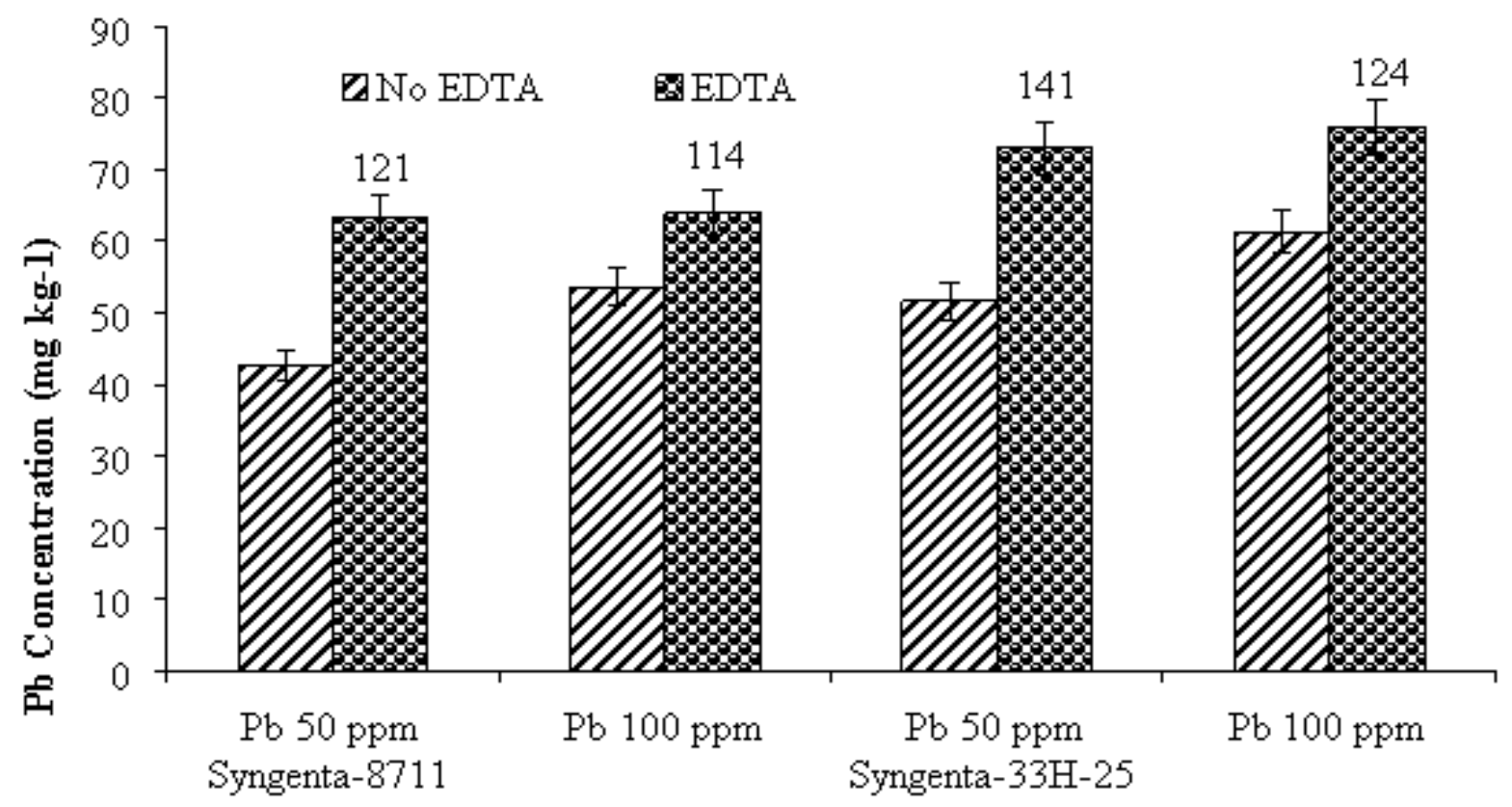

Figure 6. Effect of different concentrations of lead $(\mathrm{Pb})$ on Maize cultivars 


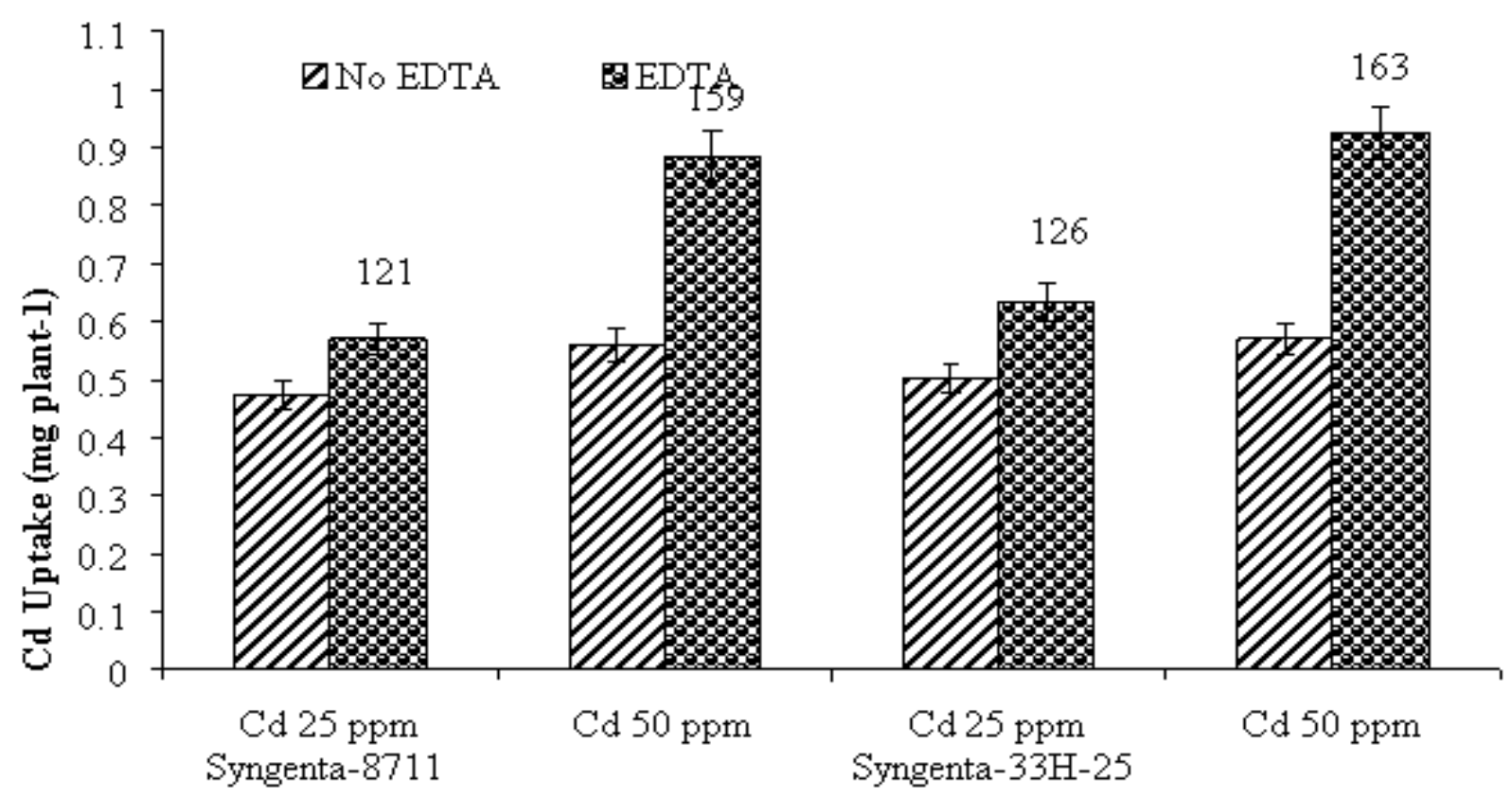

Figure 7. Uptake of different concentrations of cadmium (Cd) in Maize cultivars

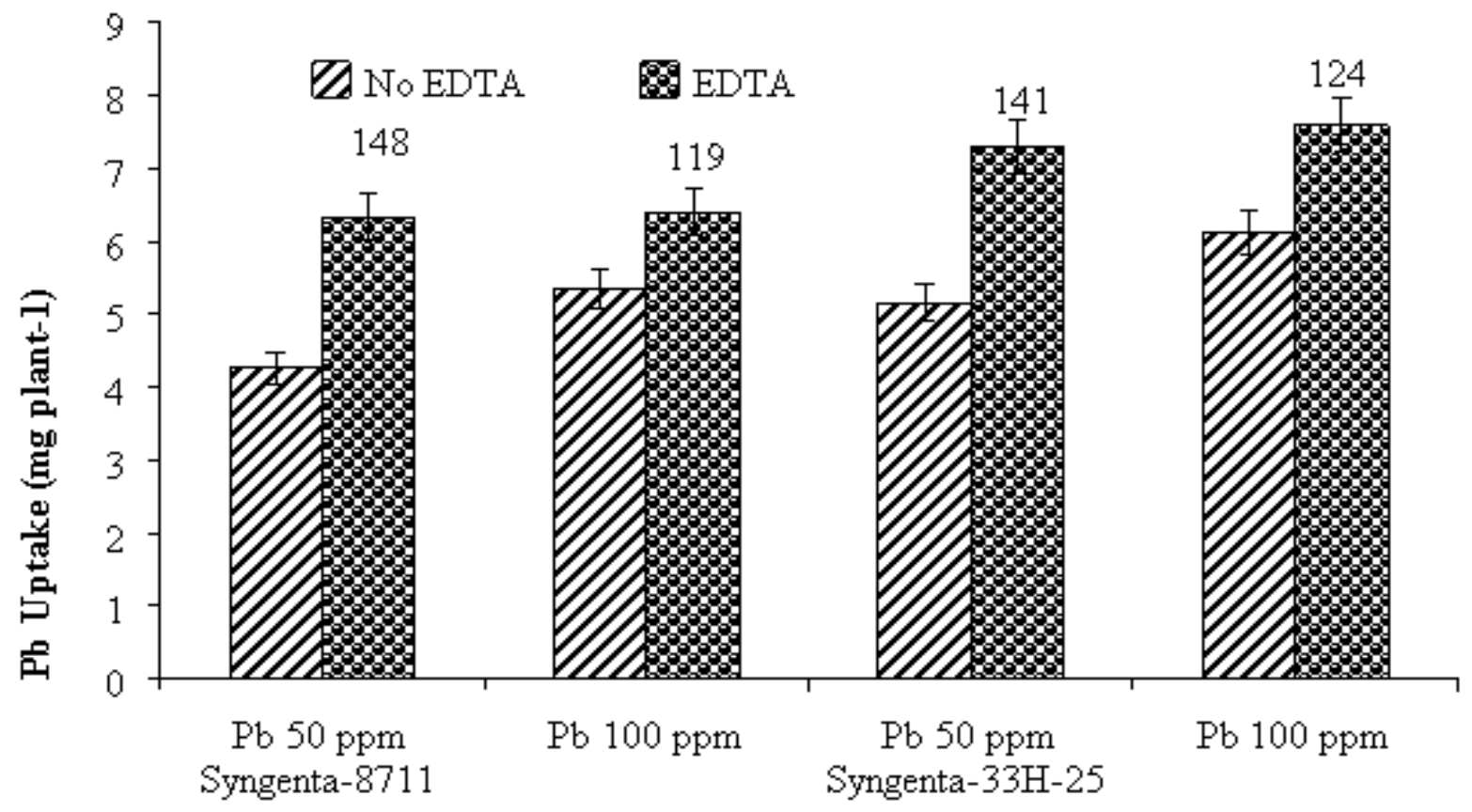

Figure 8. Uptake of different concentrations of lead $(\mathrm{Pb})$ in Maize cultivars

\section{Conclusion}

In the present study the toxic effect of heavy metals reduced the plant fresh and dry biomass, chlorophyll contents and relative water contents. The addition of chelating agent like EDTA increased the uptake of heavy metals which were observed in the term of $\mathrm{Cd}$ and $\mathrm{Pb}$ uptake. It was concluded 
that the addition of $\mathrm{Cd}$ and $\mathrm{Pb}$ decreased the overall plant biomass. The addition of EDTA increased the concentration of $\mathrm{Cd}$ and $\mathrm{Pb}$. The maize cultivar Syngenta-33H-25 accumulated more $\mathrm{Cd}$ and $\mathrm{Pb}$ as compared to maize cultivar Syngenta-8711.The $\mathrm{Cd}$ concentration of all maize cultivars was increased with increase in cadmium concentration and in the presence of EDTA as compared to no EDTA. At all the cadmium stress levels the maximum $\mathrm{Cd}$ concentration was produced in Syngenta-33-H-25.The minimum $\mathrm{Cd}$ concentration was recorded in Syngenta-8711 at all cadmium stress levels. The $\mathrm{Pb}$ concentration of all maize cultivars was increased with increase in lead concentration and in the presence of EDTA as compared to no EDTA. At all the lead stress levels the maximum $\mathrm{Pb}$ concentration was produced in Syngenta-33-H-25. The minimum $\mathrm{Pb}$ concentration was recorded in Syngenta-8711 at all lead stress levels.

\section{Authors' contributions}

Conceived and designed the experiments: $M$ Rasool \& MA Haq, Performed the experiments: M Rasool \& M Jan, Analyzed the data: M Jan \& J Iqbal, Contributed reagents/ materials/ analysis tools: J Akhtar \& M Ibrahim, Wrote the paper: M Rasool \& M Jan.

\section{Acknowledgement}

The author wish to thanks Higher Education Commission (HEC) Islamabad, Pakistan for the provisions of funds from HEC funded indigenous scholarship.

\section{References}

1. Abbaspour N, Hurrell R \& Kelishadi R (2014). Review on iron and its importance for human health. $J$ Res Medical Sci 19: 223-229.

2. Alaboudi KA, Ahmed B \& Brodie G (2020). Soil washing technology for removing heavy metals from a contaminated soil: A case study. Polish J Environ Stud 29(2).
3. Alaboudi KA, Ahmed B \& Brodie G (2020). Soil washing technology for removing heavy metals from a contaminated soil: A case study. Polish J Environ Stud 29(2).

4. Alfaraas AJ, Khairiah J, Ismail B \& Noraini J (2016). Effects of heavy metal exposure on the morphological and microscopical characteristics of the paddy plant. J Environ Biol 37: 955.

5. Ali S, Chaudhary A, Rizwan M, Anwar HT, Adrees M, Farid M, Irshad MK, Hayat T \& Anjum SA (2015). Alleviation of chromium toxicity by glycinebetaine is related to elevated antioxidant enzymes and suppressed chromium uptake and oxidative stress in wheat (Triticum aestivum L.). Environ Sci Poll Res 22: 10669-10678.

6. Alkis AM, Atakol SA, Yalmaz N, Ania RE \& Atakol O (2013). Investigation of heavy metal concentrations in some Turkish wines. J Food Compos Analys 33: 105-110.

7. Al-Wabel MI, Usman AR, El-Naggar AH, Aly AA, Ibrahim HM, Elmaghraby S \& Al-Omran A (2015). Conocarpus biochar as a soil amendment for reducing heavy metal availability and uptake by maize plants. Saudi J Biol Sci 22: 503511.

8. Amujoyegbe B, Opabode J Olayinka \& A (2007). Effect of organic and inorganic fertilizer on yield and chlorophyll content of maize (Zea mays L.) and sorghum Sorghum bicolour (L.) Moench). Afr J Biotechnol 6: 205-210.

9. Apte K \& Salvi S (2016). Household air pollution and its effects on health. Vanderbilt Avenue, New York, NY 10017.

10. Ashraf MY, Roohi M, Iqbal Z, Ashraf M, Öztürk M \& Gücel S (2016). Cadmium $(\mathrm{Cd})$ and lead $(\mathrm{Pb})$ induced changes in growth, some biochemical attributes, and mineral accumulation in 
two cultivars of Mung Bean [Vigna radiata (L.) Wilczek]. Comm. Soil Sci Plant Analy 47: 405-413.

11. Clemens S \& Ma JF (2016). Toxic heavy metal and metalloid accumulation in crop plants and foods. Ann Rev Plant Biol 67: 489-512.

12. Ensink JHJ, Simmons RW, Van WD \& Hoek R (2004). Wastewater use in Pakistan: The cases of Haroonabad and Faisalabad. In: Scott CA, Faruqui NI, Raschid-sally L, (ed.) Wastewater use in irrigated agriculture. Wallingford: $C A B$ Intern 79: 91-99.

13. Habiba US, Ali M, Farid MB, Shakoor M, Rizwan M, Ibrahim, Abbasi GH, Hayat T \& Ali B (2015). EDTA enhanced plant growth, antioxidant defense system, and phytoextraction of copper by Brassica napus L. Environ Sci Poll Res 22: 1534-1544.

14. Hoagland DR \& Arnon DI (1950). The water culture method for growing plant without soil. Califor Agric Exp Sta Cir 45: 347-39.

15. Hu BF, Chen SC, Hu J, Xia F, Xu JF, Li $Y$ \& Shi Z (2017). Application of portable XRF and VNIR sensors for rapid assessment of soil heavy metal pollution. PLoS ONE 12: e0172438.

16. He Z, Yang X, Baligar VC, Zhang T \& Stoffella PJ (2015). Heavy metal contamination of soils: Sources, indicators, and assessment. J Environ Indic 9: 17-18.

17. Irfa M, Ahmad A \& Hayat S (2014). Effect of cadmium on the growth and antioxidant enzymes in two varieties of Brassica juncea. Saudi J Biol Sci 21: 125-131.

18. Jain M, Pal M, Gupta P \& Gadre R (2007). Effect of cadmium on chlorophyll biosynthesis and enzymes of nitrogen assimilation in greening maize leaf segments: Role of 2-oxoglutarate. Indian J Exper Biol 45: 385-391.
19. Jones JRJ \& Case VW (1990). Sampling, handling, and analyzing plant tissue samples. In Soil Testing and Plant Analysis, RL Westerman (ed). pp 389428. SSSA. Madison, WI, USA.

20. Kasim WA (2005). The correlation between physiological and structural alterations induced by copper and cadmium stress in broad beans (Vicia faba L.). Egypt J Biol 7: 20-32.

21. Kibriae MG, Osman KT \& Ahmed MJ (2006). Cadmium and lead uptake by rice (Oryza sativa L.) grown in three different textured soils. Soil Environ 25: 70-77.

22. Lu Y, Luo D, Lai A, Liu G, Liu L, Long J \& Chen Y (2017). Leaching characteristics of EDTA-enhanced phytoextraction of $\mathrm{Cd}$ and $\mathrm{Pb}$ by Zea mays L. in different particle-size fractions of soil aggregates exposed to artificial rain. Environ Sci Pollu Res 24(2): 1845-1853.

23. Liu LW, Li W, Song WP \& Guo MX (2018). Remediation techniques for heavy metal- Contaminated soils: Principles and applicability. Sci Total Environ 633: 206-219.

24. Lysenko EA, Klaus AA, Pshybytko NL \& Kusnetsov VV (2015). Cadmium accumulation in chloroplasts and its impact on chloroplastic processes in barley and maize. Photosynthesis Res 125: 291-303.

25. Mahar A, Wang P, Ali A, Awasthi MK, Lahori AH, Wang Q, Li, R Zhang \& Z (2016). Challenges and opportunities in the phytoremediation of heavy metals contaminated soils: A review. Ecotoxicology and Environ Safety 126: 111-121.

26. Mahdavian K, Ghaderian SM \& Schat H (2016). $\mathrm{Pb}$ accumulation, $\mathrm{Pb}$ tolerance, antioxidants, thiols, and organic acids in metallicolous and non-metallicolous 
Peganum harmala L. under $\mathrm{Pb}$ exposure. Environ Exper Bot 126: 21-31.

27. Martell AE \& Hancock RD (2013). Metal complexes in aqueous solutions. Springer Science and Business Media.

28. Moreira H, Marques AP, Franco AR, Rangel AO \& Castro PM (2014). Phytomanagement of Cd-contaminated soils using maize (Zea mays L.) assisted by plant growth-promoting rhizobacteria. Environ Sci Poll Res 21: 9742-9753.

29. Mulungu K \& Ngombe JN (2019). Climate Change Impacts on Sustainable Maize Production in Sub-Saharan Africa: A Review. In Maize-Production and Use. Intech Open.

30. Murtaza G, Ghafoor A \& Qadir M (2008). Accumulation and implications of $\mathrm{Cd}, \mathrm{Co}$ and $\mathrm{Mn}$ in soils and vegetables irrigated with city effluent. J Sci Food Agric 88: 100-107.

31. Nazar R, Iqbal N, Masood A, Khan MIR, Syeed S \& Khan NA (2012). Cadmium toxicity in plants and role of mineral nutrients in its alleviation. Am J Plant Sci 3: 1476-1489.

32. Ochiai $K$ and Matoh $T$ (2002). Characterization of the $\mathrm{Na}^{+}$delivery from roots to shoots in rice under saline stress: excessive salt enhances apoplastic transport in rice plants. Soil Sci Plant Nutr 48: 371-378.

33. Riemenschneider C, Al-Raggad $M$, Moeder M, Seiwert B, Salameh E \& Reemtsma T (2016). Pharmaceuticals, Their Metabolites, and Other Polar Pollutants in Field-Grown Vegetables Irrigated with Treated Municipal Wastewater. J Agric Food Chem 64: 5784-5792.

34. Sarwar N, Imran M, Shaheen MR, Ishaque W, Kamran MA, Matloob A, Rehim A \& Hussain S (2016). Phytoremediation strategies for soils contaminated with heavy metals:
Modifications and future perspectives. Chemosphere 171: 710-721.

35. Seregin K (2005). Distribution of cadmium, lead, nickel, and strontium in imbibing maize caryopses. Russ J Plant Physio 4: 565-569.

36. Shaheen SM, Rinklebe J, Rupp H \& Meissner R (2014). Lysimeter trials to assess the impact of different flood-drycycles on the dynamics of pore water concentrations of As, Cr, Mo and V in a contaminated floodplain soil. Geoderma 228: 5-13.

37. Shahid M, Dumat C, Pourrut B, Silvestre J, Laplanche C \& Pinelli E (2014). Influence of EDTA and citric acid on lead-induced oxidative stress to Vicia faba roots. J Soils Sediments 14: 835843.

38. Shahid M, Pinelli E \& Dumat C (2012). Review of $\mathrm{Pb}$ availability and toxicity to plants in relation with metal speciation; role of synthetic and natural organic ligands. J Hazard Mater 219-220: 1-12.

39. Singh S, Srivastava PK, Kumar D, Tripathi DK, Chauhan DK \& Prasad SM (2015). Morpho-anatomical and biochemical adapting strategies of maize (Zea mays L.) seedlings against lead and chromium stresses. Biocatalysis Agric Biotechnol 4: 286-295.

40. Song Y, Ammami MT, Benamar A, Mezazigh S, Wang, H (2016). Effect of EDTA, EDDS, NTA and citric acid on electrokinetic remediation of $\mathrm{As}, \mathrm{Cd}, \mathrm{Cr}$, $\mathrm{Cu}, \mathrm{Ni}, \mathrm{Pb}$ and $\mathrm{Zn}$ contaminated dredged marine sediment. Environ Sci Poll Res 23: 10577-10586.

41. Steel RGD, JH Torrie \& Dickey DA (1997). Principles and Procedures of Statistics: A Biometrical Approach, $3^{\text {rd }}$ edition McGraw Hill Co., New York, USA.

42. Tariq $M$ \& Iqbal $H$ (2010). Maize in Pakistan-an overview. Kasetsart J Nat Sci 44(5): 757. 
43. Thakur S, Singh L, Wahid A, Siddiqui ZM, Atnaw FSM \& Din FSM (2016). Plant-driven removal of heavy metals from soil: uptake, translocation, tolerance mechanism, challenges, and future perspectives. Environ Monitoring Assessment 188: 1-11.

44. Van der Ent A, Baker AJ, Reeves RD, Pollard AJ \& Schat H (2013). Hyperaccumulators of metal and metalloid trace elements: facts and fiction. Plant Soil 362(1-2): 319-334.

45. Vollenweider P, Cosio C, GünthardtGoerg M \& Keller C (2006). Localization and effects of cadmium in leaves of a cadmium-tolerant willow (Salix viminalis L.): Part II Micro localization and cellular effects of cadmium. Environ Expr Bot 58(1): 2540.
46. Wuana RA \& Okieimen FE (2010). Phytoremediation potential of maize (Zea mays): A review. Afr J Gen Agric 6: 275-287.

47. Xu Y, Shi GX, Ding CX \& Xu XY (2011). Polyamine metabolism and physiological responses of Potamogeton crispus leaves under lead stress. Russ $J$ Plant Physiol 58(3): 460-466

48. Yong SO, Usman ARA, Lee SS, Abd ElAzeem, SM, Choi B, Hashimoto Y \& Yang, JE (2011). Effects of rapeseed residue on lead and cadmium availability and uptake by rice plants in heavy metal contaminated paddy soil. Chemosphere 85: 677-682.

49. Zhuang P, Yang QW, Wang HB and Shu WS (2007). Phytoextraction of heavy metals by eight plant species in the field. Water Air Soil Pollut 184: 235-242. 